\title{
Plant diseases in landrace varieties and hybrid maize cultivated using different technology levels
}

\section{Fitodoenças em variedades crioulas e híbridos de milho cultivados em diferentes sistemas tecnológicos de manejo}

\author{
Alisson Vinicius de Araujo ${ }^{1 *}$; Delacyr da Silva Brandão Junior ${ }^{2}$; \\ Izabel Cristina Pereira Vaz Ferreira ${ }^{1}$; Emuriela da Rocha Dourado ${ }^{3}$; \\ Cândido Alves da Costa ${ }^{2}$
}

\begin{abstract}
Local soil and climate conditions as well as management techniques used in maize cropping affect disease development. In the present study, the incidence and severity of diseases were evaluated in four maize genotypes cultured in three management systems with different technology levels. We tested two landrace varieties from the North of Minas Gerais state, one double-cross hybrid and 1 singlecross hybrid. The experiment was carried out using a randomized block in lays (four varieties and three management systems) and three repetitions. Disease incidence was determined by calculating the percentage of plants with symptoms, and its severity was assessed using a scale diagram to categorize symptom levels from 0 to 5 . Results were analyzed using analysis of variance followed by mean contrasts using the Scott-Knott test at a significance level of 0.05. In conclusion, cropping system affects the incidence and severity of southern rust, which is increased by high technology systems. Landrace varieties Argentino and BR da Várzea and double-cross hybrid SHS 4080 have higher resistance to southern rust than single-cross hybrid $I A C 8333$.
\end{abstract}

Key words: Maize bushy stunt phytoplasma, Puccinia polysora, Spiroplasma kunkelli, Ustylago maydis, Zea mays

\section{Resumo}

As diferentes características edafoclimáticas do país e as técnicas empregadas no milho influenciam o aparecimento de doenças. Nesse trabalho avaliou-se a incidência e a severidade de doenças em cultivares de milho cultivados em três sistemas de manejo. Foram utilizadas duas variedades crioulas do Norte de Minas Gerais, um híbrido duplo e um híbrido simples. O delineamento foi em blocos ao acaso em faixas (quatro variedades e três sistemas de manejo), com três repetições. Para as avaliações, amostrou-se 10 plantas ao acaso em cada parcela. A incidência foi determinada por meio do cálculo da porcentagem de plantas com sintomas e para a severidade utilizou-se uma escala diagramática que ordena os níveis dos sintomas de 0 a 5 . Os resultados foram submetidos à análise de variância e as médias comparadas

\footnotetext{
${ }^{1}$ Discentes de Doutorado do Programa de Pós-Graduação em Fitotecnia, Dept ${ }^{\circ}$ de Fitotecnia, Universidade Federal de Viçosa, Viçosa, MG, Brasil. E-mail: viniciusnca@yahoo.com.br; izabelcpvf@yahoo.com.br

2 Profs. DSc. do Instituto de Ciências Agrárias, Universidade Federal de Minas Gerais, Montes Claros, MG, Brasil. E-mail: dsbrandaojr@ufmg.br, candido-costa@ufmg.br

${ }^{3}$ Eng $^{\mathrm{a}}$ Agr ${ }^{\mathrm{a}}$ do Centro de Agricultura Alternativa do Norte de Minas, CAA/NM, Montes Claros, MG, Brasil. E-mail: muridourado@ yahoo.com.br

* Author for correspondence
} 
pelo teste de Scott-Knott a 5\% de probabilidade. Foi possível concluir que os níveis tecnológicos de manejo empregados no cultivo do milho interferem na incidência e severidade da ferrugem polysora. A utilização mais intensa de tecnologia nessa cultura favorece o desenvolvimento dessa doença nos genótipos analisados. As variedades crioulas Argentino e BR da Várzea e o hibrido duplo SHS 4080 possuem maior resistência a ferrugem polysora do que o hibrido simples IAC 8333.

Palavras-chave: Maize bushy stunt phytoplasma, Puccinia polysora, Spiroplasma kunkelli, Ustylago maydis, Zea mays

\section{Introduction}

Maize cropping is affected by several plant diseases. Some of them were firstly considered secondary, but from the 1990s onward their incidence and severity increased expressively. A number of factors explain the dissemination of maize diseases, such as increase of land use for cropping, diversification of commercial varieties of different resistance levels to diseases, sequential cropping throughout the year, inadequate irrigation and no tillage on maize crop residues (MASSOLA JÚNIOR, 2001; PINTO, 2004). According to Alves et al. (2001), physiological disturbances increase plant vulnerability and consequently favor disease proliferation. These authors state that pathogenic organisms readily absorb amino acids and reducing sugars from soluble mineral fertilizers, insecticides and fungicides that are not absorbed by plants. This nutritional disturbance underlies trophobiosis theory (CHABOUSSOU, 1980), which considers that plants are infested only if they contain soluble nutritive substances that meet the nutritional needs of parasites such as pathogen organisms.

Interaction of different soil and climate characteristics and the techniques and inputs used for maize cropping in Brazil affect disease emergence. Organic fertilization combined with different soil preparation and use of plant varieties highly adapted to the cropping area may produce maize plants with an elevated state of physiological equilibrium and more resistant to infestations (SANGOI et al., 2000). Moreover, the organic fertilizer used as nutrient source must be considered because it increases maize yield provided it is incorporated into the soil over the years (MARIN; MENEZES; SALCEDO, 2007).
Recent studies show that the higher the investments in management practices, the higher the maize grain production (SANGOI et al., 2003; RIBEIRO et al., 2005; FORSTHOFER et al., 2006). However, the implementation of conventional agricultural technologies may become unfeasible owing to increased energy costs (mainly from nonrenewable sources).

Landrace varieties have lower production costs, and are therefore commonly grown in areas with low cropping technology. Rustic landraces are adapted to the adverse soil and climate conditions and management systems used by family farmers (MOREIRA; LOPES; SILVA, 2002). Additionally, farmers themselves can produce landrace seeds at no expense. The study of crop behavior and production potential of landrace and commercial maize varieties grown in different areas and management systems provides valuable information to assist farmers and technicians in making cropping decisions, especially because it helps to identify limiting production factors, such as plant diseases. Accordingly, the present study aimed to verify the effect of three management systems, with different levels of technology, in the incidence and severity of plant diseases in landraces and commercial maize.

\section{Material and Methods}

The study was conducted in the experimental field of the Instituto de Ciências Agrárias of the Universidade Federal de Minas Gerais, in Montes Claros, Brazil (435' 'W longitude, $16^{\circ} 43^{\prime}$ S latitude and $650 \mathrm{~m}$ altitude). Climate in this area is dry-wet 
tropical savanna (Aw in Köppen's classification), and mean annual temperature in the 2009/2010 harvest was $24.2^{\circ} \mathrm{C}$. Soil properties in the surface layer $(0-20 \mathrm{~cm})$ were determined before sowing (Table 1). The soil in the experimental field is an Oxisol (FAO, 2006).

Table 1. Chemical and textural soil characteristics at 0-20 cm depth in areas used for growing maize crops in systems with three technology levels.

\begin{tabular}{lccc}
\hline \multicolumn{1}{c}{ Characteristics } & High & Moderate & Low \\
\hline $\mathrm{pH}($ in water) & 7.7 & 7.3 & 7.3 \\
$\mathrm{P} \mathrm{Mehlich}\left(\mathrm{mg} \mathrm{kg}^{-1}\right)$ & 16.9 & 14.9 & 16.4 \\
Remaining P $\left(\mathrm{mg} \mathrm{L}^{-1}\right)$ & 26.0 & 24.7 & 24.0 \\
$\mathrm{~K}\left(\mathrm{mg} \mathrm{kg}^{-1}\right)$ & 353 & 894 & 382 \\
$\mathrm{Ca}\left(\mathrm{cmolc} \mathrm{dm}^{-3}\right)$ & 8.80 & 7.40 & 8.60 \\
$\mathrm{Mg}\left(\mathrm{cmolc} \mathrm{dm}^{-3}\right)$ & 1.20 & 2.00 & 2.00 \\
$\mathrm{Al}\left(\mathrm{cmolc} \mathrm{dm}^{-3}\right)$ & 0.00 & 0.00 & 0.00 \\
$\mathrm{H}+\mathrm{Al}\left(\mathrm{cmolc} \mathrm{dm}^{-3}\right)$ & 0.89 & 0.95 & 0.95 \\
$\mathrm{SB}\left(\mathrm{cmolc} \mathrm{dm}^{-3}\right)$ & 10.90 & 11.69 & 11.58 \\
$\mathrm{t}\left(\mathrm{cmolc} \mathrm{dm}^{-3}\right)$ & 10.90 & 11.69 & 11.58 \\
$\mathrm{~m}(\%)$ & 0 & 0 & 0 \\
$\mathrm{~T}\left(\mathrm{cmolc} \mathrm{dm}{ }^{-3}\right)$ & 11.80 & 12.65 & 12.53 \\
$\mathrm{~V}(\%)$ & 92 & 92 & 92 \\
Organic Matter $\left(\mathrm{dag} \mathrm{kg}^{-1}\right)$ & 3.23 & 3.08 & 3.23 \\
Soil Texture & medium & medium & medium \\
\hline
\end{tabular}

Source: Elaboration of the authors.

The experiment was carried out using a randomized block design in a $4 \times 3$ factorial arrangement (four maize genotypes $x$ three management systems), in lays, with three repetitions per treatment. Each plot had four 5-meter long rows, $0.80 \mathrm{~cm}$ apart. Maize seeds were sown five centimeter deep at a density of five plant $\mathrm{m}^{-1}$, totaling 62,500 plants $\mathrm{ha}^{-1}$. We cultivated two landrace varieties traditionally cultured in the North of Minas Gerais, known to farmers as Argentino and $B R d a$ Várzea, double-cross hybrid cultivar SHS 4080 and single-cross hybrid cultivar IAC 8333. Management systems were classified as low, moderate and high technology systems.

In the low technology system crop inputs and pest control were not provided and soil was ploughed with an animal-drawn moldboard plough and weeds were hand pulled. This system did not include artificial irrigation, and micro sprinkler irrigation had to be installed because of the extended drought period during the experiments. Irrigation was stopped at the onset of grain filling.

Soil preparation in the moderate technology system included conventional soil management with a tractor-pulled disc harrow. According to chemical soil analysis (Table 1) and crop needs, we applied seven kilogram cattle manure per meter. We also applied topdressing fertilization with 10 $\mathrm{L} \mathrm{m}^{-1}$ of biofertilizer obtained from an anaerobic biodigester. Weeds were controlled by hand pulling, Spodoptera frugiperda (J.E. Smith) was controlled using a biopesticide with $0.7 \%$ Neem oil (Azadirachta indica A. Juss.) and irrigation was applied as described for the low technology system.

In the high technology system, soil was prepared 
by conventional practices, using deep plough and two tractor-pulled harrow passes. Fertilization was applied as a function of chemical soil analysis (Table 1) and crop needs. Thus, the crop was fertilized with $246.15 \mathrm{~kg} \mathrm{ha}^{-1}$ of 4:30:10 NPK at sowing time and thereafter received topdressing fertilization with $500 \mathrm{~kg} \mathrm{ha}^{-1}$ ammonium sulfate and $20 \mathrm{~kg} \mathrm{ha}^{-1}$ potassium chlorate. The weed control was done with $5.57 \mathrm{~L} \mathrm{ha}^{-1}$ of the herbicide atrazine and Spodoptera frugiperda was controlled using $0.096 \mathrm{~L} \mathrm{~h}^{-1}\left(480 \mathrm{~g} \mathrm{~L}^{-1}\right)$ of the synthetic insecticide triflumuron. Microsprinkler irrigation was supplied from sowing to grain filling (BERGAMASCHI et al., 2004).

To evaluate the incidence of disease were sampled randomly, 10 plants situated in two rows and the innermost plot of one meter from the edge. The incidence of systemic diseases, such as maize bushy stunt and corn stunt, and diseases where a single infection is enough to impede grain commercialization, such as corn smut, was quantified according to the presence or not of symptoms (AMORIM, 1995). Leaf diseases such as rusts are quantified by both their incidence and severity, which reflect symptoms (AMORIM, 1995). Disease severity was evaluated using a diagram scale for maize crops proposed by Azevedo (1997). It ranks symptom levels from zero to five according to the leaf area affected: $0=$ asymptomatic; $1=10 \%$ of leaf area; $2=20 \%$ of leaf area; $3=60 \%$ of leaf area; $4=80 \%$ of leaf area; and $5=100 \%$ of leaf area. At the grain filling stage three different researchers examined the same leaves, and the mean score of these evaluations was used in statistical analyses, as proposed by Sangoi et al. (2000).

The percent values of incidence were transformed using arcsin $\sqrt{ }(\% / 100)$, and diagram scale scores were transformed using the equation $\sqrt{ }(x+0.5)$. Transformed data were analyzed using analysis of variance, and mean values were contrasted using the Scott-Knott test at a significance level of 0.05 .

\section{Results and Discussion}

The diseases detected in the experiment were southern rust, maize bushy stunt, corn stunt and corn smut. Southern rust was the prevailing disease, with the highest incidence (76.94\%). Caused by the fungus Puccinia polysora Undrew, this disease is currently one of the most important diseases of maize in Brazil and is considered the most aggressive rusts that occur on this crop (OLIVEIRA et al., 2004). This disease compromises the quality and quantity of maize seeds and grains produced, reducing production by $44.6 \%$ in susceptible maize hybrids (PINTO, 2004).

The incidence of maize bushy stunt and corn stunt was relatively low ( 0.17 and $0.06 \%$, respectively), although some authors report significant increases in Brazil in recent years, especially in the Southeast and Midwest regions, causing relevant economic losses (OLIVEIRA et al., 1998; TOFFANELLI; BEDENDO, 2001). Corn leafhoppers (Dalbulus maidis DeLong \& Wolcott) are the main disseminators of maize bushy stunt and corn stunt phytoplasmas. For instance, Giménez Pecci et al. (2002) found a low incidence of phytoplasmacaused diseases in Argentine crops in which the occurrence of corn leafhoppers Dalbulus maidis was also low, likely because in these areas maize cropping was limited to the rainy season, which is unsuitable to these insects.

Corn smut infestation was low $(0.11 \%)$, corroborating studies of Moura, Pedrosa and Guimaraes (2001), which reported that, despite being endemic, this disease does not infest more than $1 \%$ of the maize crop in Northeast Brazil. The damage caused by corn smut includes grain yield reduction due to sterility, ear destruction, as well as a decrease in forage biomass and carbohydrate level. However, grain yield is not severely affected (MOURA; PEDROSA; GUIMARAES, 2001).

The incidence and severity of southern rust were affected by the factors evaluated (technology level and genotype), but interaction was not detected. 
The highest prevalence and severity of southern rust in maize was found in crops using the high technology system tested (Table 2). Statistical analyses detected that rust severity increased along with the technology level used for maize cropping. Although some studies did not find infestation differences in maize crops treated with different nitrogen levels (PEGORARO et al., 2001), others report that higher nitrogen levels increase maize infection by this southern rust (DURÃES et al., 2004). Bedendo (1995) states that soil fertility and agrochemical use may favor plant vulnerability to pathogen attack. According to this author, the herbicide 2,4-D increases wheat susceptibility to attack by Puccinia sp. and other fungi. Soil nutrient imbalance may alter the biochemical and structural mechanisms of host defenses (BALARDIN et al., 2006; PRATISSOLI et al., 2007).

Table 2. Incidence and severity of southern rust in four maize varieties grown in systems with three technology levels.

\begin{tabular}{ccc}
\hline Systems & Incidence $(\%)^{1}$ & Severity \\
High technology & $88.33 \mathrm{a}$ & $0.89 \mathrm{a}$ \\
Moderate technology & $75.83 \mathrm{~b}$ & $0.44 \mathrm{~b}$ \\
Low technology & $66.67 \mathrm{~b}$ & $0.10 \mathrm{c}$ \\
\hline F test (Systems) & $5.59^{*}$ & $13.15^{* *}$ \\
\hline Genotypes & & \\
Single cross hybrid IAC 8333 & $97.74 \mathrm{a}$ & $1.07 \mathrm{a}$ \\
Double cross hybrid SHS 4080 & $78.89 \mathrm{~b}$ & $0.21 \mathrm{~b}$ \\
Landrace Argentino & $56.67 \mathrm{~b}$ & $0.47 \mathrm{~b}$ \\
Landrace BR da Várzea & $74.44 \mathrm{~b}$ & $0.17 \mathrm{~b}$ \\
\hline F test (Genotypes) & $8.60^{* *}$ & $10.73^{* *}$ \\
\hline F test (Systems x Genotypes) & $0,56^{\text {ns }}$ & $1.85^{\text {ns }}$ \\
\hline CV $(\%)$ & 23.43 & 15.34 \\
\hline
\end{tabular}

${ }^{1}$ Means followed by a same letter in a column are not statistically different (Scott-Knott test, $\mathrm{P}>0.05$ ).

${ }^{2}$ Severity grades ranked from 0 to 5 , where: $0=$ asymptomatic; $1=10 \%$ of leaf area attacked; $2=20 \%$ of leaf area attacked; $3=$ $60 \%$ of leaf area attacked; $4=80 \%$ of leaf area attacked; and $5=100 \%$ of leaf area attacked (AZEVEDO, 1997).

${ }^{n s}$ Non-significant by the $\mathrm{F}$ test.

* Significant at $1 \%$ level by the $\mathrm{F}$ test.

** Significant at 5\% level by the F test.

Source: Elaboration of the authors.

Based on trophobiosis theory (CHABOUSSOU, 1980), the agrochemicals used in the area cultivated with high technology likely caused an imbalance in nutritional soil properties, thereby compromising plant defense mechanisms and resistance to diseases. By contrast, plants cultivated with a low technology system, which were not treated with fertilizers, herbicides and chemical or natural insecticides, likely have lower free amino acid content and consequently lower vulnerability to parasites. Seguy, Bouzinac and Maronezzi (1999) found that no tillage technology reduces fungal and bacterial diseases in upland rice crops in the North of Mato
Grosso state and cottonseed crops in the South of Goiás. They also explain this phenomenon by the trophobiosis theory, underscoring the importance of soluble metabolites in contaminating and infecting plants with pathogenic fungi and viruses.

The maize varieties tested exhibited different vulnerability to southern rust, which was more severe in the single-cross hybrid than in the other varieties tested (Table 2). The landrace varieties (Argentino and BR da Várzea) and double-cross hybrid SHS 4080 were not statistically different. These results show that not only management 
technology but also the adaptation and rusticity provided by genetic characteristics of cultivars affect disease development. Resistance has been considered one of the most effective forms to control southern rust in maize crops (SWEETS, 2009), and the availability of wide genetic diversity may contribute positively to that end (SILVA et al., 2001). At this point, landrace varieties deserve attention due to their high genetic variability and consequent adaptation to adverse crop environments (MENEGUETTI; GIRARDI; REGINATTO, 2002), which is not observed in highly productive modern varieties that are greatly dependent on the use of agricultural inputs.

\section{Conclusions}

The landrace varieties Argentino and $B R d a$ Várzea and double- cross hybrid SHS 4080 have higher resistance to southern rust than single-cross hybrid $I A C$ 8333. The use of chemical fertilizers, herbicides and synthetic insecticides promotes southern rust development in maize crops. Organic management and the use of landrace varieties enable the development of maize crops that are more tolerant to plant pathogens.

\section{Acknowledgements}

To CAPES and FAPEMIG for providing postgraduation fellowships to A.V. Araujo and I.C.P.V. Ferreira, respectively, and to $\mathrm{CNPq}$, for partial financial support.

\section{References}

ALVES, S. B.; MEDEIROS, M. B.; TAMAI, M. A.; LOPES, R. B. Trofobiose e microrganismos na proteção de plantas: biofertilizantes e entomopatógenos na citricultura orgânica. Biotecnologia Ciência \& Desenvolvimento, n. 21, p. 16-21, 2001. Available at: $<$ http://www.biotecnologia.com.br/revista/bio21/21_4. pdf $>$. Accessed at: 15 nov. 2010.

AMORIM, L. Avaliação de doenças. In: BERGAMIN
FILHO, A. Manual de fitopatologia. São Paulo: Agronômica Ceres, 1995. cap. 32, p. 647-671.

AZEVEDO, L. A. S. Manual de quantificação de doenças de plantas. São Paulo: Novartis, 1997. 114 p.

BALARDIN, R. S.; DALLAGNO, L. J.; DIDONÉ, H. T.; NAVARINI, L. Influence of phosphorus and potassium on severity of soy bean rust, Phakopsora pachyrhizi. Fitopatologia Brasileira, Brasília, v. 31, p. 462-467, 2006. Available at: <http://www.scielo.br/scielo. php?pid $=$ S0100-41582006000500005\& script $=$ sci arttext>. Accessed at: 5 oct. 2010.

BEDENDO, I. P. Ambiente e doença. In: BERGAMIN FILHO, A.; KIMATI, H.; AMORIM, L. Manual de fitopatologia. São Paulo: Agronômica Ceres, 1995. cap. 18, p. 331-342.

BERGAMASCHI, H.; DALMAGO, G. A.; BERGONCI, J. I.; BIANCHI, C. A. M.; MULLER, A. G.; COMIRAN, F.; HECKLER, B. M. M. Water supply in the critical period of maize and the grain production. Pesquisa Agropecuária Brasileira, Brasília, v. 39, p. 831-839, 2004. Available at: <http://www.scielo.br/scielo. php?script=sci_arttext\&pid=S0100-204X200400090000 $1 \& \operatorname{lng}=$ en\&nrm=iso $>$. Accessed at: 15 oct. 2010.

CHABOUSSOU, F. Les plantes malades des pesticides. Paris: Editions Débard, 1980. 265 p.

DURÃES, F. O. M.; MAGALHÃES, P. C.; MARRIEL, I. E.; GAMA, E. E. G.; CASELA, C. R.; OLIVEIRA, A. C.; CANTÃO, F. R. O. Caracterização de genótipos para uso e eficiência de nitrogênio em milho e influência da adubação nitrogenada sobre a incidência e severidade da mancha foliar de Phaesphaeria maydis. Sete Lagoas: Embrapa Milho e Sorgo, 2004. 8 p. (Embrapa Milho e Sorgo. Circular técnica, 53).

FOOD AND AGRICULTURE ORGANIZATION FAO. World reference base for soil resources 2006: a framework for international classification, correlation and communication. Rome, Italy: FAO, 2006. 145 p. (World Soil Resources Report, 103).

FORSTHOFER, E. L.; SILVA, P. R. F.; STRIEDER, M. L.; MINETTO, T.; RAMBO, L.; ARGENTA, G.; SANGOI, L.; SUHRE, E.; SILVA, A. A. Agronomic yield and economic performance of maize in different management levels and sowing times. Pesquisa Agropecuária Brasileira, Brasília. v. 41, p. 399-407, 2006. Available at: <http://www.scielo.br/scielo. php?script=sci_arttext\&pid=S0100-204X200600030000 $5 \& \operatorname{lng}=$ en\&nrm $=$ iso $>$. Accessed at: 8 nov. 2010.

GIMÉNEZ PECCI, M. P.; OLIVEIRA, E.; RESENDE, R. O.; LAGUNA, I. G.; CONCI, L. R.; AVILA, A.; HERRERA, P.; GALDEANO, E.; VIRLA, E.; NOME, 
C. F. Occurrence of corn stunt diseases and maize viruses in the Provinces of Tucumán and Córdoba in Argentina. Fitopatologia Brasileira, Brasília, v. 27, n. 4, p. 403-407, 2002. Available at: <http://www. scielo.br/scielo.php?script=sci_arttext\&pid=S0100$41582002000400012 \& \operatorname{lng}=$ en\&nrm $=$ iso $>$. Accessed at: 13 sept. 2011.

MARIN, A. M. P.; MENEZES, R. S. C.; SALCEDO, I. H. Productivity of maize intercropped or not with gliricidia ammended with two organic fertilizers. Pesquisa Agropecuária Brasileira, Brasília, v. 42, n. 5, p. 669677, 2007. Available at: <http://www.scielo.br/scielo. php?script=sci_arttext\&pid=S0100-204X200700050000 9\&lng=en\&nrm=iso $>$. Accessed at: 20 sept. 2010.

MASSOLA JÚNIOR, N. S. Maize bush stunt and corn stunt: diseases of corn caused by molicutes. Semina: Ciências Agrárias, Londrina, v. 22, n. 2, p. 237-243, 2001. Available at: http://www.uel.br/portal/frm/ frmOpcao.php?opcao=http://www.uel.br/revistas/uel/ index.php/semagrarias. Accessed: 18 nov. 2010.

MENEGUETTI, G. A.; GIRARDI, J. L.; REGINATTO, J. C. Milho crioulo: tecnologia viável e sustentável. Agroecologia e Desenvolvimento Sustentável, v. 3, n. 1, p. 12-17, 2002.

MOREIRA, L. B.; LOPES, H. M.; SILVA, E. R. Effects of seed size, organic manure rates and sowing densities in the performance of maize (Zea mays L.). Agronomia, v. 36, n. 1-2, p. 37-41, 2002.

MOURA, R. M.; PEDROSA, E. M. R.; GUIMARAES, L. M. P. A rare syndrome of corn smut. Fitopatologia Brasileira, Brasília, v. 26, n. 4, p. 782, 2001. Available at: $<$ http://www.scielo.br/scielo.php?script=sci_arttext\&pid $=\mathrm{S} 0100-41582001000400021 \& \operatorname{lng}=\mathrm{en} \& \mathrm{nrm}=\mathrm{iso}>$. Accessed at: 6 oct. 2010.

OLIVEIRA, E.; FERNANDES, F. T.; CASELA, C. R.; PINTO, N. F. J. A.; FERREIRA, A. S. Diagnose e controle de doenças na cultura do milho. In: GALVÃO, J. C. C.; MIRANDA, G. V. Tecnologias de produção do milho. Viçosa: UFV, 2004. p. 228-268.

OLIVEIRA, E.; WAQUIL, J. M.; FERNANDES, F. T.; PAIVA, E.; RESENDE, R. O.; KITAJIMA, W. E. Enfezamento pálido e enfezamento vermelho na cultura do milho no Brasil Central. Fitopatologia Brasileira, Brasília, v. 23, p. 45-47, 1998.

PEGORARO, D. G.; VACARO, E.; NUSS, C. N.; SOGLIO, F. K. D.; SERENO, M. J. C. M.; BARBOSA NETO, J. F. Effect of planting date and fertilization on Phaeosphaeria leaf blight in maize. Pesquisa Agropecuária Brasileira, Brasília, v. 36, n. 8, p. 10371042, 2001. Available at: <http://www.scielo.br/scielo.
php?script=sci_arttext\&pid=S0100-204X200100080000 $5 \& \operatorname{lng}=$ en\&nrm $=$ iso $>$. Accessed at: 30 nov. 2010.

PINTO, N. F. J. A. Chemical control of foliar diseases in corn. Revista Brasileira de Milho e Sorgo, Sete Lagoas, v. 3, n. 1, p. 134-138, 2004.

PRATISSOLI, D.; ALMEIDA, G. D.; JESUS JÚNIOR, W. C.; VICENTINI, V. B.; HOLTZ, A. M.; COCHETO, J. G. Biofertilizer and silicate clay as resistance inductors to the black spot of papaya disease. Idesia, v. 25, p. $63-67,2007$. Available at: <http://www. scielo.cl/scielo.php?script=sci_arttext\&pid $=\mathrm{S} 0718$ $34292007000200008 \& \operatorname{lng}=$ en\& $^{-}-{ }^{-}=$iso $>$. Accessed at: 4 sept. 2010.

RIBEIRO, N. A.; CASA, R. T.; BOGO, A.; SANGOI, L.; MOREIRA, E. N.; WILLE, L. A. Incidence of stalk rot, rot grains and grain yield of maize genotypes in different management systems. Ciência Rural, Santa Maria, v. 21, n. 1, p. 1003-1009, 2005. Available at: <http://www. scielo.br/scielo.php?script=sci_arttext\&pid=S0103$84782005000500004 \& \operatorname{lng}=$ en\&nrm $=$ iso $>$. Accessed at: 30 nov. 2010 .

SANGOI, L.; ENDER, M.; GUIDOLIN, A. F.; BOGO, A.; KOTHE, D. M. Disease incidence and severity of four maize hybrids grown at different plant densities. Ciência Rural, Santa Maria, v. 30, n. 1, p. 17-21, 2000. Available at: $<$ http://www.scielo.br/scielo.php?script=sci arttext\&pid=S0103-84782000000100003\&lng=en\&nrm $=$ iso $>$. Accessed at: 17 oct. 2010.

SANGOI, L.; ARGENTA, G.; SILVA, P. R. F.; MINETTO, T. J.; BISOTTO, V. Maize management levels at two contrasting environmentes: technical and economical analysis. Ciência Rural, Santa Maria, v. 33, n. 6 , p. 1021-1029, 2003. Available at: <http://www. scielo.br/scielo.php?script=sci_arttext\&pid=S0103$84782003000600005 \& \operatorname{lng}=$ en\&nrm=iso $>$. Accessed at: 20 sept. 2010.

SEGUY, L.; BOUZINAC, S.; MARONEZZI, A. C. Plantio direto e resistência das culturas às doenças. Informações Agronômicas, Piracicaba, n. 88, p. 1-3, 1999.

SILVA, H. P.; BARBOSA, M. P. M.; NASS, L. L.; CAMARGO, L. E. A. Combining capacity and heterosis for resistance to Puccinia polysora Underw. in maize. Scientia Agrícola, Piracicaba, v. 58, n. 4, p. 777-783, 2001. Available at: <http://www. scielo.br/scielo.php?script=sci_arttext\&pid=S010390162001000400020\&lng=en\&nrm=iso $>$. Accessed at: 5 oct. 2010.

SWEETS, L. Corn foliage diseases. Integrated Pest and Crop Management, v. 19, n. 15, p. 99-102, 2009. 
TOFFANELLI, C. M.; BEDENDO, I. P. Effect of the inoculation of the maize bushy stunt phytoplasma on the development and kernel yield of corn hybrids. Fitopatologia Brasileira, Brasília, v. 26, n. 4, p. 756-760, 2001. Available at: <http://www. scielo.br/scielo.php? script $=$ sci_arttext\&pid $=\mathrm{S} 0100$ $41582001000400012 \& \operatorname{lng}=$ en\& $\& r m=i s o>$. Accessed at: 28 sept. 2010. 